\title{
KONTRIBUSI SEMIOTIKA DALAM MEMAHAMI BAHASA AL-QUR'AN
}

\author{
Akhmad Muzakki*
}

\begin{abstract}
A bstract: The texts of the Qur'an may be understood as a collection of symbols, and cannot be interpreted in isolation from the context as their background. If semiotics is a science of symbols, then the texts of the Qur'an must be the fertile object for the study of semiotics. In the science of semiotics, texts are deemed to have no end in themselves, meaning that we must not acknowledge them as having ended or being finalized at some point Some philosophers such as J acques Derrida have underscored this, and maintained that language is a metaphor. A meaning that we assume resulted from our use of language is in fact the product of the metaphorical exchange. Hence, a meaning will change as soon as the subject of the metaphorical exchange changes. Meaning in other words is both dynamic and relational because it is based on an endless source.
\end{abstract}

Keywords: symbol, symbolizing, marking, parole, langue, ikon, indeks

\section{Pendahuluan}

Pemahaman terhadap al-Qur'an yang diyakini sebagai kitab salinh li kull zaman wa makan selalu bersifat terbuka dan tidak pernah selesai. Pemahaman selalu berkembang seiring dengan umat Islam yang selalu terlibat dalam penafsiran ulang dari zaman ke zaman. Dengan begitu, tidak semua doktrin dan pemahaman agama berlaku sepanjang waktu dan tempat mengingat gagasan universal Islam tidak semuanya tertampung dalam bahasa yang bersifat lokal-kultural, serta terungkap melalui tradisi kenabian. Itulah sebabnya dari zaman ke zaman selalu muncul ulama-ulama tafsir yang berusaha mengaktualkan pesan-pesan al-Qur'an yang tidak mengenal batas akhir. ${ }^{1}$

Dalam proses pemahaman terdapat tiga faktor yang tidak bisa dipisahkan, yaitu dunia pengarang, dunia teks, dan dunia pembaca. Selain ketiga faktor ini keberadaan konteks juga sangat berperan dalam memahami peristiwa pewahyuan, sebab ayat-ayat al-Q ur'an tidak akan dapat dimengerti dengan sempurna kecuali dengan memperhatikan realitas yang melatarbelakanginya. Indikasi ini dapat dilihat dengan munculnya konsep asbāb al-nuzūl dan nāsikh wa mansükh yang menjadi tema tersendiri dalam studi ulūm al-Q ur'an. O leh sebab itu, memahami historisitas teks al-Qur'an menjadi penting, meskipun jarak antara pengarang teks (Tuhan) dan manusia sebagai pembaca demikian jauh agar makna dan pesan moral tersebut bisa direfleksikan seiring dengan kemaslahatan.

Perbincangan masalah historitas teks sebenarnya merupakan persoalan klasik yang pernah muncul dalam sejarah peradaban Islam, yaitu antara pemikir Ash'ariyah dengan Mu'tazilah. $\mathrm{H}$ istoritas teks, seperti yang dipahami $\mathrm{Nasr} \mathrm{H}$ āmid² dengan meminjam paradigma Ferdinand de Saussure, konsep kalām ia bedakan dengan konsep lughah. Lughah yang dimaksud setara

*Universitas Islam Negeri (UIN) Maulana Malik Ibrahim Malang,

${ }^{1}$ Komaruddin Hidayat, Memahami Bahasa Agama: Sebauh Kajian Hermeneutik (J akarta: Paramadina, 1996), 26.

${ }^{2} \mathrm{~N}$ asr Hāmid Abū Zayd, Naqd al-Khimāb al-Dīn̄i (Kairo: J umhūrīyah Micr al-'Arabīyah, 1994), 87. 
dengan apa yang diistilahkan Saussure dengan langue (bukan parole), yaitu bahasa pada wilayah realitas historis yang dalam hal ini merupakan bagian dari kebudayaan. Sementara Toshihiko Izutsu ${ }^{3}$ menyebut dengan istilah lisān, bukan lughah seperti Nasr Hamid. Kalām merupakan sisi parole, sedangkan lisān merupakan sisi langue. Kalām dan lisān dalam bahasa Arab kira-kira sepadan dengan parole dan langue dalam bahasa Perancis.

Dalam pengertian umum, langue adalah abstraksi dan artikulasi bahasa pada tingkat sosial budaya, sedangkan parole merupakan ekspresi bahasa pada tingkat individu. ${ }^{4}$ Berdasarkan kerangka ini maka dalam kajian teks-teks al-Q ur'an terdapat perbedaan yang tegas antara konsep kalām (yang a-historis) dengan lughah (yang historis). ${ }^{5} \mathrm{H}$ istorisitas teks tidak hanya meliputi ruang dan waktu, melainkan sekaligus ia adalah sebuah teks yang berkaitan erat dengan teks lainnya yang akan menentukan makna teks itu sendiri.

J adi, teks-teks agama (lughah) tidak terpisah dari struktur budaya tempat ia terbentuk. Sumber teks sama sekali tidak mengenyampingkan hakikat keberadaannya sebagai teks linguistik dengan segala implikasi kebahasaannya. Teks terkait dengan ruang dan waktu dalam pengertian historis dan sosio logis. Teks tidak berada di luar kategori bahasa sehingga tidak memiliki kaitan apapun dengan manusia. J ika berinteraksi dengan teks agama ini bertolak dari keberadaannya sebagai linguistik, maka ini tidak berarti mengabaikan watak tekstualitasnya yang spesifik. Sebab karakter tekstualitas al-Q ur'an didasarkan pada realitas-realitas kemanusiaan yang provan, yang bersifat sosiologis, kultural, dan kebahasaan. Keberadaan firman Tuhan yang kudus baru menjadi perhatian hanya pada momen di mana "kalām tersebut diposisikan secara manusiawi", yaitu ketika Muhammad mengujarakannya dalam bahasa Arab. ${ }^{6}$

Dengan mengikuti kerangka berpikir Saussure di mana bahasa dianggap sebagai proses langue, maka tanda-tanda bahasa merupakan fakta sosial. Karena tanda-tanda bahasa mengacu pada konsep dan gambaran mental yang berdiam dalam masyarakat. Artinya, bahwa bahasa barada dalam inti kebudayaan. Dari pengertian ini para semiot mengatakan, bahwa kebudayaan merupakan ekspresi dari berbagai sistem tanda yang pusatnya adalah tanda bahasa. Sehingga keberadaan bahasa dan lingkungan kulturalnya menjadi rujukan untuk menemukan maknanya. Berangkat dari logika ini, al-Qur'an yang menjadi kitab suci juga dapat dipahami dan dikonstruks melalui perkembangan studi budaya, khususnya bidang kajian semiotika.

Komaruddin Hidayat mengatakan, sejak Tuhan "berbicara" itulah maka Islam lahir sebagai agama. la bukan hanya sebagai fakta historis, melainkan sebuah kehadiran Tuhan dalam bentuk "kalam". Ia diwahyukan Tuhan untuk menyapa manusia dan mengajaknya ke jalan keselamatan.

${ }^{3}$ Toshihiko Izutsu, Relasi Tuhan dan Manusia: Pendekatan Semantik terhadap al-Qur'an, ter. Agus Fahri H usein, dkk (Yogyakarta: PT Tiara Wacana Yogya, 1997), 116.

${ }^{4}$ Komaruddin, Memahami Bahasa Agama, 23.

${ }^{5}$ Bahasa agama (baca al-Q ur'aø) secara historis-antropologis adalah bahasa manusia, tetapi secara teologis di dalamnya memuat kalām Ilāhī yang bersifat tranhistoris, atau metahistoris. Bahwa apa yang di sebut dengan kitab suci sesungguhnya bukan kalam Tuhan in toto dan verbatim, melainkan sudah merupakan "produk bersama" yang di dalamnya terdapat gagasan Tuhan yang kemudian dipahami dan diterjemahkan Mu\%ammad ke dalam lisan A rab. Itulah sebabnya, maka al-Q ur’ ān mengenal konsep asbāb al-nuzül di mana isi dan pesan memiliki hubungan dialektis dengan konteks sosial dan situasi psikologis pribadi Muhammad saw. Jadi, al-Q ur`ān dalam satu sisi dipandang sebagai kalām II $\bar{a} h \bar{\imath}$, dan pada sisi yang lain merupakan produk budaya karena telah diartikulasikan Muhammad melalui bahasa Arab. Komaruddin, Memahami B ahasa Agama, 86.

${ }^{6}$ Ibid., 118. 
Di situ teks kitab suci berdiri secara otonom, menampilkan dirinya melalui jaringan sistem tanda sehingga memungkinkan pembaca mengajak dialog dengannnya. Posisi kitab suci yang semula sebagai subyek yang mencari Muhammad sebagai obyeknya, beralih sebagai dokumen yang pasif dan menunggu kehadiran pembaca yang akan merespon dan menafsirkannya. Pada tahap ini semiotika menjadi satu-satunya ilmu yang terpenting untuk mendekati teks kitab suci. ${ }^{7}$

\section{Semiotika: Perkenalan Awal}

Semiotika merupakan sebuah model ilmu pengetahuan sosial dalam memahami dunia sebagai sistem hubungan yang memiliki unit dasar yang disebut "tanda". Semiotika berasal dari kata Yunani, semeion yang berarti tanda. Tanda itu sendiri didefinisikan sebagai sesuatu yang dapat mewakili sesuatu yang lain atas dasar konvensi sosial. ${ }^{8}$ Istilah semiotika sering digunakan bersama dengan istilah semiologi. Dalam kedua istilah ini tidak terdapat perbedaan yang substantif, tergantung di mana istilah itu populer. Biasanya semiotika lebih mengarah pada tradisi Piercean, sementara istilah semiologi banyak digunakan oleh kubu Saussure. Namun, yang terakhir jika dibandingkan dengan yang pertama kian jarang dipakai, ada kecenderungan istilah semiotika lebih populer dari pada semiologi, sehingga para penganut mazhab Saussurean pun sering menggunakan istilah semiotika. Namun yang jelas, keduanya merupakan ilmu yang mempelajari hubungan antara signs (tanda-tanda) berdasarkan kode-kode tertentu. Tanda-tanda tersebut akan tampak pada tindak komunikasi manusia lewat bahasa.

Semiotika adalah ilmu tentang tanda-tanda. Ilmu ini menganggap bahwa fenomena sosial atau masyarakat dan kebudayaannya merupakan tanda-tanda. Artinya, semiotika mempelajari sistem-sistem, aturan-aturan, konvensi-konvensi yang memungkinkan tanda-tanda tersebut mempunyai arti. Dengan kata lain, semiotika mempelajari relasi di antara komponen-komponen tanda, serta relasi antara komponen-komponen tersebut dengan masyarakat penggunanya.

Ada beberapa elemen dasar dalam kajian semiotika di antaranya; (i) komponen tanda, (ii) aksis tanda, (iii) tingkatan tanda, dan (iv) relasi antar tanda.

\section{Komponen Tanda}

Dalam perkembangannya, semiotika menganut dikotomi bahasa yang dikembangkan Saussure, yaitu tanda (sign) memiliki hubungan antara penanda (signifiant/signifier) dan petanda (signifie/signified). Penanda adalah aspek material, seperti suara, huruf, bentuk, gambar, dan gerak, sedangkan petanda adalah aspek mental atau konseptual yang ditunjuk oleh aspek material. Kedua aspek ini, yaitu penanda dan petanda kemudian disebut komponen tanda. Suara yang muncul dari sebuah kata yang diucapkan merupakan penanda, sedang konsepnya adalah petanda. Sehingga keberadaan dua unsur ini tidak bisa dipisahkan, dan pemisahan hanya akan mengaburkan pengertian kata (tanda) itu sendiri.

Dalam pandangan Saussure, tanda adalah kesatuan dari suatu bentuk penanda dengan sebuah ide, atau petanda. Dengan lain kata, penanda adalah bunyi atau coretan yang bermakna. J adi penanda adalah aspek material dari bahasa, apa yang dikatakan atau didengar, dan apa yang ditulis atau dibaca. Sedangkan petanda adalah gambaran mental, pikiran, atau

${ }^{7}$ lbid., 116.

${ }^{8} \mathrm{U}$ mberto Eco, A Theory of Semiotics (Bloomington: Indiana University Press, 1976), 16. 
konsep. J adi petanda adalah aspek mental dari bahasa. ${ }^{9}$

2. Aksis Tanda

Di dalam konteks strukturalisme bahasa, tanda tidak dapat dilihat hanya secara individu, akan tetapi dalam relasi dan kombinasinya dengan tanda-tanda lain di dalam sebuah sistem. Analisis tanda berdasarkan sistem atau kombinasi yang lebih besar ini melibatkan apa yang disebut aturan pengkombinasian yang terdiri dari dua aksis tanda, yaitu aksis sintagmatik dan aksis paradigmatik.

Aksis sintagmatik adalah sebuah relasi yang merujuk kepada hubungan in praesentia di antara satu kata dengan kata-kata yang lain, atau antara satuan gramatikal dengan satuan gramatikal yang lain di dalam ujaran atau tindak tutur (speech act). Karena tuturan selalu diekspresikan sebagai suatu rangkaian tanda-tanda verbal dalam dimensi waktu, maka relasirelasi sintagmatik kadang disebut juga relasi-relasi linear. Atau, satu perangkat tanda (seperti kamus) yang melaluinya pilihan-pilihan dibuat, dan hanya satu di antara pilihan tersebut yang dapat dipilih.

Aksis sintagmatik ini berkebalikan dengan relasi asosiatif, yang di dalam linguistik pasca Saussure disebut sebagai aksis paradigmatik. Di dalam relasi ini setiap tanda berada di dalam kodenya sebagai bagian dari suatu paradigma, suatu sistem relasi in absentia yang mengaitkan tanda-tanda tersebut dengan tanda-tanda lain sebelum ia muncul dalam tuturan. ${ }^{10}$ Dengan lain kata, aksis paradigmatik adalah cara pemilihan dan pengombinasian tanda-tanda berdasarkan aturan atau kode tertentu, sehingga dapat menghasilkan sebuah ekspresi bermakna.

Kode adalah seperangkat aturan bersama atau konvensi yang di dalamnya tanda-tanda dapat dikombinasikan, sehingga memungkinkan pesan dikomunikasikan dari seseorang kepada orang lain. Kode merupakan aturan yang menghasilkan tanda-tanda sebagai penampilan konkritnya di dalam hubungan komunikasi. Implisit dalam pengertian kode di atas adalah adanya kesepakatan sosial di antara anggota komunitas bahasa tentang kombinasi seperangkat tanda-tanda dan maknanya. ${ }^{11}$

3. Tingkatan Tanda

Salah satu area penting yang dirambah Roland Barthes dalam studinya tentang tanda adalah tingkatan tanda, yaitu tingkat denotasi dan konotasi. Denotasi adalah tingkat pertandaan yang menjelaskan hubungan antara penanda dan petanda, atau antara tanda dan rujukannya pada realitas, yang menghasilkan makna yang eksplisit, langsung, dan pasti. Makna denotasi dalam hal ini adalah makna pada apa yang tampak.

Konotasi adalah tingkat pertandaan yang menjelaskan hubungan antara penanda dan petanda yang di dalamnya beroperasi makna yang tidak eksplisit, tidak langsung, dan tidak pasti (terbuka terhadap berbagai kemungkinan). la menciptakan makna-makna lapis kedua yang terbentuk ketika penanda dikaitkan dengan berbagai aspek psikologis, seperti perasaan,

\footnotetext{
${ }^{9} \mathrm{~K}$. B ertens, Filsafat Barat K ontemporer Prancis (J akarta: Gramedia, 2001), 180.

${ }^{10}$ Kris Budiman, Semiotika Visual, 42.

${ }^{11}$ Yasraf Amir Piliang, Hipersemiotika: Tafsir Cultural Studies A tas Matinya Makna (Yogyakarta: J alasutra, 2003), 259.
} 
emosi, atau keyakinan. Misalnya, tanda bunga, ia mengkonotasikan kasih sayang. Konotasi dapat menghasilkan makna lapis kedua yang bersifat implisit, tersembunyi, inilah yang disebut makna konotatif. ${ }^{12}$

J adi, denotasi adalah makna paling nyata dari tanda, sedangkan konotasi adalah istilah yang menunjukkan signifikasi tahap kedua. Konotasi mempunyai makna yang subyektif atau paling tidak intersubyektif. Dengan kata lain, denotasi adalah apa yang digambarkan tanda terhadap obyek, sementara konotasi adalah bagaimana menggambarkan tanda tersebut. ${ }^{13}$

4. Relasi Antar Tanda

Selain kombinasi tanda, analisis semiotika juga berupaya mengungkap interaksi di antara tanda-tanda. M eskipun bentuk interaksi antara tanda-tanda ini sangat luas, akan tetapi ada dua bentuk interaksi utama yang dikenal, yaitu metafora dan metonimi.

Metafora adalah sebuah model interaksi tanda, yang di dalamnya sebuah tanda dari sebuah sistem digunakan untuk menjelaskan makna untuk sebuah sistem yang lainnya. Misalnya penggunaan metafora "kepala batu" untuk menjelaskan seseorang yang tidak mau diubah pikirannya.

Metonimi adalah interaksi tanda, yang di dalamnya sebuah tanda diasosiasikan dengan tanda lain, yang di dalamnya juga terdapat hubungan bagian dengan keseluruhan. Misalnya, tanda "botol" (bagian) untuk mewakili pemabuk (total), atau, tanda "mahkota" untuk mewakili konsep tentang kerajaan. ${ }^{14}$

\section{Bahasa sebagai Tanda}

Dalam dunia semiotika (ilmu tanda), seperti ungkap de Saussure ${ }^{15}$, bahasa dianggap sebagai "tanda" (sign) ${ }^{16}$ yang memiliki komponen signifiant dan signifie. Melakukan analisis tentang tanda orang harus tahu benar mana aspek material dan mana aspek mental. Ketiga aspek ini merupakan aspek-aspek konstitutif suatu tanda, tanpa salah satu unsur ini tidak akan ada sebuah tanda dan kita tidak bisa membicarakannya, bahkan tidak bisa membayangkannya.

Selain tanda, ada istilah lain yang seringkali dipersamakan, yaitu simbol dan lambang.

\footnotetext{
${ }^{12}$ |bid.,261.

${ }^{13}$ Alex Sobur, Analisis Teks Media: Suatu Pengantar untuk Analisis Wacana, Analisis Semiotik, dan Analisis Framing (Bandung: Rosda Karya, 2001), 128.

${ }^{14}$ Piliang, H ipersemiotika, 262.

${ }^{15}$ Aart van Zoest, "Interpretasi dan Semiotika" dalam Serba-serbi Semiotika (J akarta: Gramedia Pustaka Utama, 1996), 2.

${ }^{16} \mathrm{Kalau}$ setiap bahasa dianggap sebagai tanda, maka seperti yang dikatakan U mberto Eco ruang lingkup semiotika sangatlah luas sehingga menimbulkan kesan "imperialisme". Namun dalam hal ini, penulis menyandarkan pada pernyataan Charles Morris, bahwa obyek kajian semiotika pada dasarnya dapat dibedakan ke dalam tiga cabang; pertama, sintaktika, yaitu cabang penyelidikan semiotika yang mengkaji hubungan formal di antara satu tanda dengan tanda-tanda yang lain. Dengan kata lain, karena hubungan-hubungan formal ini merupakan kaidah-kaidah yang mengendalikan tuturan dan interpretasi, maka pengertian sintaktik kurang lebih adalah semacam "gramatika". Kedua, semantika yaitu cabang penyelidikan semiotika yang mempelajari hubungan di antara tanda-tanda dengan designata atau obyek-obyek yang diacunya. Yang dimaksud designata adalah makna tanda-tanda sebelum digunakan di dalam tuturan tertentu. Ketiga, pragmatika yaitu cabang penyelidikan semiotika yang mempelajari hubungan di antara tanda-tanda dengan interpreter-interpreter atau para pemakai tanda-tanda. Pragmatik secara khusus berurusan dengan aspek-aspek komunikasi, khususnya fungsi-fungsi situasional yang melatari tuturan. Kris Budiman, Semiotika Visual (Yogyakarta: Buku Baik, 2003), 5.
} 
Menurut Robert Sibarani, dengan mengutip pendapat van Zoest, ${ }_{17}^{17}$ simbol adalah sesuatu yang dapat menyimbolkan dan mewakili ide, pikiran, perasaan, benda, dan tindakan secara arbitrer, konvensional, dan representatif-interpretatif. Dalam hal ini, tidak ada hubungan alamiah antara yang menyimbolkan dan yang disimbolkan. Implikasinya berarti, baik yang batiniyah (perasaan, pikiran, atau ide) maupun yang lahiriah (benda dan tindakan) dapat diwakili dengan simbol.

Sementara dalam konsep Peirce, simbol diartikan sebagai tanda yang mengacu pada obyek tertentu di luar tanda itu sendiri. Hubungan antara simbol sebagai penanda dengan sesuatu yang ditandakan (petanda) sifatnya konvensional. Berdasarkan konvensi itu pula masyarakat pemakainya menafsirkan ciri hubungan antara simbol dengan obyek yang diacu dan menafsirkan maknanya. Dalam arti demikian, kata misalnya, merupakan salah satu bentuk simbol karena hubungan kata dengan dunia acuannya ditentukan berdasarkan kaidah kebahasaannya. Kaidah kebahasaannya itu secara artifisial ditentukan berdasarkan konvensi masyarakat pemakainya.

Dalam bahasa komunikasi, simbol seringkali diistilahkan sebagai lambang. Lambang sebenarnya juga adalah tanda. Hanya bedanya lambang tidak memberi tanda secara langsung, melainkan melalui sesuatu yang lain. Warna merah pada bendera sang merah putih merupakan lambang "keberanian", dan putih lambang "kesucian". Seperti kata O gden dan Richard, lambang ini bersifat konvensional. Simbol atau lambang adalah sesuatu yang digunakan untuk menunjuk sesuatu lainnya berdasarkan kesepakatan kelompok orang. Lambang meliputi kata-kata (pesan verbal), perilaku non-verbal, dan obyek yang maknanya disepakati bersama, misalnya memasang bendera di halaman rumah untuk menyatakan penghormatan atau kecintaan kepada negara.

Dari penjelasan di atas, simbol dan lambang merupakan salah satu dari kategori tanda (sign). Sebagaimana dalam wawasan Peirce, bahwa tanda (sign) terdiri atas ikon (icon), indeks (index), dan simbol (symbol). Pada dasarnya ikon merupakan tanda yang bisa menggambarkan ciri utama sesuatu meskipun sesuatu yang lazim disebut sebagai obyek acuan tersebut tidak hadir. Hubungan antara tanda dengan obyek dapat juga direpresentasikan oleh ikon dan indeks, namun ikon dan indeks tidak memerlukan kesepakatan. Kemudian, istilah simbol dalam pandangan Peirce lazim disebut kata (word), nama (name), dan label (label). Sebab itu tidak mengherankan apabila pengertian tanda, simbol, maupun kata seringkali tumpang tindih. ${ }^{18}$

\section{Langue dan Parole}

Dalam konsep Saussure, trio langage-langue-parole dipergunakan untuk menegaskan obyek kajian linguistiknya. Fenomena bahasa secara umum disebutnya langage, sedangkan langue dan parole merupakan bagian dari langage. Parole adalah menifestasi individu terhadap bahasa yang dapat memberikan makna, sedangkan langue adalah bahasa dalam proses sosial. Saussure dalam hal ini menitikberatkan studi linguistiknya pada langue, karena ia menaruh perhatian pada tanda-tanda bahasa atau kode-kode bahasa. ${ }^{19}$

Langue adalah bahasa sebagai obyek sosial yang murni, dan dengan demikian

\footnotetext{
${ }^{17}$ Wahyu Wibowo, Manajemen Bahasa, Pengorganisasian Karangan Pragmatik dalam Bahasa Indonesia untuk Mahasiswa dan Praktisi Bisnis (J akarta: Gramedia Pustaka Utama, 2001), 3.

${ }^{18}$ Alex Sobur, Semiotika Komunikasi (Bandung: Remaja Rosdakarya, 2004), 159.

${ }^{19}$ Mudjia Rahardjo, Wacana Kebahasaan dari Filsafat H ingga Sosial-Politik (Malang: Cendekia Paramulya, 2004), 7.
} 
keberadaannya terletak di luar individu, yakni sebagai seperangkat konvensi-konvensi sistematik yang berperan penting di dalam komunikasi. Langue juga merupakan institusi sosial yang otonom, tidak tergantung kepada materi tanda-tanda pembentuknya. Sebagai sebuah institusi sosial, langue sama sekali bukan tindakan dan tak bisa pula dirancang, diciptakan, atau diubah secara pribadi karena ia pada hakekatnya merupakan kontrak kolektif yang sungguh-sungguh mesti dipatuhi apabila kita ingin bisa berkomunikasi. ${ }^{20}$ Langue adalah bahasa dalam wujudnya sebagai suatu sistem. la merupakan fakta sosial. J adi, langue adalah suatu sistem kode yang diketahui oleh semua anggota masyarakat pemakai bahasa tersebut, seolah-olah kode tersebut telah disepakati bersama di masa lalu di antara pemakai bahasa.

Di samping sebagai institusi sosial, langue adalah sekaligus sebuah sistem nilai. Bila sebagai institusi sosial langue pada dasarnya merupakan kontrak kolektif yang harus diterima secara menyeluruh bila kita hendak berkomunikasi, maka sebagai sistem nilai langue tersusun atas sejumlah elemen yang sekaligus merupakan ekuivalen dari kuantitas benda-benda dan termaterma yang berfungsi lebih luas di dalam sebuah tatanan perbedaan. Dilihat dari sisi ini, sebuah tanda dapat kita umpamakan seperti keping uang logam (koin) yang bernilai sejumlah barang tertentu, dengan demikian, dapat dibelanjakan, tetapi ia juga memiliki nilai dalam kaitannya dengan koin-koin yang lain.

Berkebalikan dengan itu, parole merupakan bagian dari bahasa yang sepenuhnya individual. Parole dapat dipandang, pertama, sebagai kombinasi yang memungkinkan penutur mampu menggunakan kode bahasa untuk mengungkapkan pikiran pribadinya. Di samping itu, kedua, parole pun dapat dipandang sebagai mekanisme psiko-fisik yang memungkinkan penutur menampilkan kombinasi tersebut. Aspek kombinatif ini mengimplikasikan bahwa parole tersusun dari tanda-tanda yang identik dan senantiasa berulang. Karena adanya keberulangan inilah maka setiap tanda bisa menjadi elemen dari langue. J uga karena merupakan aktivitas kombinatif ini pulalah, maka parole terkait dengan tindakan individual dan bukan semata-mata sebentuk kreasi. Secara singkat dapat dikatakan bahwa parole merupakan penggunaan aktual bahasa sebagai tindakan individu-individu. ${ }^{21}$

Menurut Alex Sobur ${ }^{22}$ ada perbedaan substansial antara langue dan parole, di antaranya; pertama, langue mempunyai obyek studi berupa tanda atau kode, sementara parole adalah living speech, yaitu bahasa yang hidup, atau bahasa sebagaimana terlihat dalam penggunaannya. Kedua, langue bersifat kolektif dan pemakaiannya tidak disadari oleh pengguna bahasa, sementara parole lebih memperhatikan faktor pribadi pengguna bahasa. Ketiga, unit dasar langue adalah kata, sementara unit dasar parole adalah kalimat. Keempat, langue bersifat sinkronik, dalam arti tanda itu dianggap baku sehingga mudah disusun sebagai sistem, sementara parole boleh dianggap bersifat diakronik, dalam arti sangat terikat oleh dimensi waktu saat terjadi proses pembicaraan.

Secara implisit dapat ditangkap bahwa langue dan parole beroposisi, tatapi sekaligus juga saling tergantung. Itu berarti bahwa tidak ada yang lebih utama. Di satu pihak sistem yang berlaku

${ }^{20}$ Kris Budiman, Semiotika Visual, 38.

${ }^{21}$ lbid., 38.

${ }^{22}$ Sobur, Semiotika Komunikasi, 50. 
dalam langue adalah hasil produksi dari kegiatan parole, di lain pihak pengungkapan parole serta pemahamannya hanya mungkin berdasarkan penelusuran langue sebagai sistem. Langue sebagai gudang tanda dari semua ungkapan parole tidaklah merupakan kumpulan dari ungkapan-ungkapan secara kebetulan, melainkan terdiri atas sebuah sistem dari unsur-unsur dan hubungan yang mendasari sistem tersebut. ${ }^{23}$

Terkait dengan bahasa agama, khususnya al-Qur'an seperti yang dipahami Nasr Hamid dengan meminjam kerangka Saussure, konsep kalām ia bedakan dengan konsep lughah. Lughah yang dimaksud setara dengan apa yang diistilahkan langue, yaitu bahasa pada wilayah historis yang dalam hal ini merupakan bagian dari kebudayaan, sedangkan kalām merupakan sisi parole. Dalam pengertian umum, langue adalah abstraksi dan artikulasi bahasa pada tingkat sosial budaya, sedangkan parole merupakan ekspresi bahasa pada tingkat individu. Dengan demikian, terdapat perbedaan yang tegas antara konsep kalām (yang a-historis) dengan lughah (yang historis).

Dengan demikian, terdapat perbedaan yang tegas antara konsep kalām (yang a-historis) dengan lughah (yang historis). Dengan mengikuti kerangka berpikir de Saussure di mana obyek studi linguistiknya menitiberatkan pada bahasa sebagai proses langue, maka tanda-tanda bahasa merupakan fakta sosial. Karena tanda-tanda bahasa tidak mengarah pada realitas eksternalobyektif secara langsung, tetapi mengacu pada konsep dan gambaran mental yang berdiam dalam kesadaran masyarakat, maka ini berarti bahwa bahasa barada dalam inti kebudayaan, sekalipun terejawantah dalam berbagai manifestasi. Dari sini para ahli semiotika mengatakan bahwa kebudayaan adalah ekspresi dari berbagai sistem tanda yang inti pusatnya adalah sistem tanda berupa bahasa.

Karena itu, al-Q ur'an yang historis tidak terpisah dari struktur budaya tempatia terbentuk. Sumber teks sama sekali tidak mengenyampingkan hakikat keberadaannya sebagai teks linguistik dengan segala implikasi kebahasaannya. Teks terkait dengan ruang dan waktu dalam pengertian historis dan sosiologis. Teks tidak berada di luar kategori bahasa sehingga tidak memiliki kaitan apapun dengan manusia. Jika berinteraksi dengan teks agama ini dan bertolak dari keberadaannya sebagai linguistik, maka hal ini tidak berarti mengabaikan watak tekstualitasnya yang spesifik.

\section{Kontribusi Semiotika}

Apabila semiotika dipahami sebagai ilmu tentang tanda maka al-Qur'an khususnya konsep langue atau lughah yang historis menjadi bidang subur bagi analisis semiotik, bukan parole atau firman yang a-historis. Tanda memainkan peran penting dalam agama dan itu dengan berbagai cara yang perlu dibedakan. Pertama, dalam agama dunia ciptaan dengan berbagai aspeknya sering digambarkan sebagai tanda Allah. Kedua, kitab-kitab wahyu yang menjadi salah satu dasar kebanyakan agama, dapat dianggap sebagai himpunan tanda yang menunjukkan makna tertentu yang perlu digali dalam proses penafsiran. Ketiga, teks-teks wahyu

\footnotetext{
${ }^{23}$ Martin Krampen, "Ferdinand de Saussure dan Perkembangan Semiologi" dalam Serba-Serbi Semiotika, penyunting Panuti Sudjiman dan Aart van Zoest (J akarta: PT G ramedia Pustaka Utama, 1996), 57.
} 
pada umumnya dianggap sebagai himpunan tanda yang menyampaikan pesan atau amanat Ilahi. Dan keempat, pembicaraan mengenai agama dapat dianalisis sebagai himpunan tanda. ${ }^{24}$ Misalnya, dalam surat al-Baqarah ayat 65 disebutkan, bahwa umat Ban̄̄ Isrä̀ pernah melanggar perintah Nabi Musā, yaitu ketika mereka diperintah beribadah kepada Allah pada hari Sabtu justru mereka pergi bernelayan ke laut, karena pada hari itu tidak seperti hari-hari biasanya ikan di laut sangat banyak. Kemudian Allah mengutuk mereka, "J adilah kamu kera yang hina". Sebagian ahli tafsir memandang bahwa ini sebagai suatu perumpamaan, artinya mereka menyerupai hati kera karena sama-sama tidak menerima nasehat dan peringatan. Namun berbeda dengan pendapat jumhur, mereka betul-betul berubah menjadi kera, hanya tidak beranak, tidak makan dan minum, dan mereka hidup tidak lebih dari tiga hari lagi.

Secara denotatif makna qiradah adalah kera, tetapi jika kembali kepada konsep Barthes bahwa sebuah tanda selain memiliki tingkatan makna denotatif juga mengandung makna konotatif. Barangkali dalam ayat di atas yang dimaksud dengan tanda "kera" adalah satu bentuk ungkapan metaforik-simbolik. Sehingga kaum Banī Israłł yang melanggar titah Nabi Musā tidak ubahnya seperti kera. Artinya, mereka memiliki sifat-sifat seperti kera, misalnya rakus, tamak, serakah, membangkang, dan seterusnya. Inilah yang dimaksud dengan pengertian makna pada tataran kedua, yaitu makna konotatif. Sebuah proses dari petanda yang membentuk penanda baru untuk menghasilkan significance.

Sebagai bahan perbandingan juga perhatikan surat al-A'rafayat 166, “Maka tatkala mereka bersikap sombong terhadap apa yang mereka dilarang mengerjakannya, Kami katakan kepadanya, "J adilah kamu kera yang hina". Secara nalar, akal kita tidak bisa membaca kalau Allah mengutuk kaum Bani Israßł lantaran mereka tidak mau taat kepada perintah-Nya, karena mereka sombong, congkak, dan takabbur. Kita tahu dan meyakini bahwa Allah adalah Maha Kasih, Maha Sayang, Maha Pemurah, dan Maha lainnya. Dengan demikian, sangat jelas kalau yang dimaksud dengan qiradah pada ayat di atas adalah bahasa kias, atau bahasa perumpamaan (simile/tashbih h).

Dalam wacana hermeneutika disebutkan, bahwa makna teks akan selalu berubah-rubah bergantung kepada konteks pembacaan. Berkaitan dengan ini kita dapat mengkaji kembali konsep makna yang dikembangkan $\mathrm{Nasr} \mathrm{Hamid},{ }^{25}$ ia menyatakan, dalam kajian terhadap teks keagamaan makna dapat dibedakan menjadi dua, yaitu; i) makna yang khusus (tarikhił, dan ii) makna yang umun (daim mustamirr). Dalam hal ini ia tidak berkompetisi membedakan antara konsep di atas dengan konsep yang telah digagas oleh ulama ucul al-fiqh dan ulūm al-Q ur'an. Konsep khās\$)dan ‘amm adalah dua sisi makna dalam teks. Yang khusus merupakan sisi semantik yang secara langsung mengacu pada realitas kultural-historis untuk memproduksi teks, sementara yang umum merupakan sisi dinamis, dapat berubah seiring dengan setiap pembacaan. Dengan ungkapan lain, perbedaan tersebut merupakan perbedaan antara makna parsial yang temporal dengan makna umum yang universal. Yang parsial dapat berubah melalui interpretasi metaforis

\footnotetext{
24J ohan Meuleman, "Sumbangan dan Batas Semiotika dalam IImu Agama", dalam Tradisi, Kemodernan dan Metamodernisme: Memperbincangkan Pemikiran Muhammed Arkoun, ed. J ohan H endrik Meuleman (Yogyakarta: LKiS, 1996), 35.

${ }^{25} \mathrm{~N}$ asr Hāmid, Naqd al-K hităb, 209.
} 
menjadi universal.

Misalnya dalam al-Q ur'an surat Q uraish ayat 2 disebutkan, "Kebiasaan mereka bepergian pada musim dingin dan musim panas". Makna khās\$(khusus) dari ayat di atas adalah sebuah fenomena kebiasaan orang-orang Quraish yang mengadakan perjalanan terutama untuk berdagang ke negeri Syam pada musim panas dan ke negeri Yaman pada musim dingin. Dalam perjalanan itu mereka mendapatjaminan keamanan dari para penguasa negeri yang dilaluinya. Ini adalah salah satu ni'mat yang amatbesar dari Tuhan kepada mereka. Karena itu, sewajarnyalah bila mereka menyembah Allah yang telah memberikan ni'mat itu kepada mereka.

Mengikuti paradigma Nasr, bahwa makna umum merupakan sisi dinamis teks yang dapat berubah seiring dengan setiap pembacaan. Misalnya, dalam konteks Indonesia, kata ilaf memiliki asumsi makna lain (bukan kebiasaan) yaitu bersatu, rukun, dan berkumpul. Karena term îlaf berakar dari kata ulfah yang berarti kerukunan, persatuan, persahabatan, dan persetujuan. Dalam kerangka semiotika tanda ilaf yang sekaligus sebagai penanda memiliki makna "bersatu" yang merujuk kepada fenomena masyarakat dan bangsa Indonesia (sebagai referent). J uga dengan kata al-shitasdan al-cayf, selain memiliki makna leksikal (makna khusus) yaitu musim dingin dan musim panas juga memiliki pengertian bahwa penduduk Indonesia boleh melakukan transmigrasi, atau berpindah dari suatu daerah ke daerah lain, dari daerah yang panas (tidak subur, gersang, tandus) menuju daerah yang dingin (subur, produktif), atau sebaliknya, dan mereka mendapatkan jaminan perlindungan undang-undang yang menjadi falsafah negara (makna umum). Mereka yang berpindah karena memenuhi kebutuhan hajat hidupnya dilindungi UUD 1945 pasal 33, sedangkan yang berpindah karena mempertahankan agama dan keyakinnannya juga dilindungi UUD 1945 pasal 29, dan sebagainya. Yang jelas, penduduk Indonesia seperti halnya fenomena masyarakat Quraish ketika melakukan perjalanan dan perdagangan mereka mendapatkan jaminan keamanan dari pihak penguasa.

Dalam memahami makna kata keberadaan teks dan konteks tidak bisa dipisahkan, di mana keduanya telah menjalin dialektika. Teks tidak lahir dari ruang hampa, tetapi teks pada umumnya merupakan respon terhadap situasi yang dihadapi dalam ruang dan waktu tertentu. Teks yang kita baca lahir karena ada konteks atau faktor yang melatarbelakangi. Bila pemahaman hanya terfokus kepada teks semata dengan mengabaikan konteks yang melahirkannya maka kita akan terjebak pada kekaburan bahasa. Karena itu, makna dari sebuah kata baru dapat dikatakan benar apabila kita mengetahui siapa pembicaranya dan siapa pendengarnya. Atas pernyataan ini, para ahli wacana apabila menganalisis kata atau kalimat terlebih dahulu mereka menganalisis konteksnya.

Seperti kata acnām (berhala), ia adalah tanda sekaligus sebagai penanda yang merujuk pada referent tertentu. Kalau pada masa Nabi Ibrāhīm hingga masa Nabi Muhammad saat beliau menyampaikan dakwahnya di tengah-tengah kehidupan umat makna atau petanda acnām sangat jelas, yaitu merujuk pada berhala, patung, arca, atau sejenisnya (makna denotasi dalam istilah Barthes). Namun dalam konteks sekarang makna acnām barangkali tidak sebatas itu, mungkin berupa jabatan, kedudukan, kekayaan, dan sebagainya yang kesemuanya dapat melalaikan manusia kepada Tuhan, bahkan mempersekutukan-Nya (makna konotasi dalam istilah Barthes). Artinya, makna kata acnām tersebut bergantung pada situasi dan konteks di mana kata itu 
diungkapakan. Begitu juga dengan kata-kata lainnya, seperti nūr, jannah, nār, shaymān atau iblīs, dan seterusnya.

Di dalam al-Q ur'an kita temukan banyak ayat mengenai kata fuqara'’dan masākin. Secara normatif, kita melihat fuqara'sdan masākin sebagai kelompok yang perlu dikasihani dan diberikan zakat atau sedekah. Pada hal kata fuqara'’dan masākin merupakan simbol atau tanda (penanda/ signifiant) yang perlu diinterpretasi maknanya (petanda/signifie) sehingga bisa menemukan rujukan yang jelas (referent) dalam konteks yang lebih real, faktual, serta sesuai dengan kondisi sosial, ekonomi dan kultural. B egitu juga dengan istilah yatīm, secara shar'i adalah orang yang ditinggal ayahnya. Dalam rumah tangga seorang ayah berfungsi untuk memberikan perlindungan, keamanan, kesejahteraan, dan sebagainya. Tatkala orang yang mampu memberikan segalanya telah meninggal maka sang anak disebut yatīm karena ia sangat membutuhkan pertolongan terkait dengan masa depannya. Fenomena seperti ini sering kita temukan dalam bentuk yang berbeda, namun memiliki substansi yang sama. Seseorang dengan kekuasaan dan jabatan yang disandangnya terkadang menutup muka ketika melihat orangorang yang terisolir akibat kebijakan-kebijakan politis. Sekelompok orang tergusur dari posisinya akibat perbedaan ideologi dan pandangan hidup dengan atasannya. J uga dengan pejabat pemerintah terkadang apatis ketika melihat orang-orang yang dirampas hak-haknya. Secara sosiologis, kondisi mereka yang memerlukan bantuan orang lain untuk mempertahankan eksistensi kehidupannya dapat dikategorikan sebagai anak "yatim".

Dalam dunia semiotika sendiri, dikotomi antara signifikasi dan significance, sekaligus menggambarkan dikotomi antara langue dan parole, dan pada tingkat filosofis antara paham idealisme dan materialisme. Ada kecenderungan pada wacana bahasa di Barat untuk melihat dikotomi ini sebagai layaknya pilihan multiple choic, yakni memilih salah satu dari dua kutub yang ekstrim.

Islam, seperti yang dapat dibuktikan tidak melihat dua hal yang berseberangan ini sebagai satu dikotomi atau oposisi biner seperti pilihan ganda, melainkan dua hal yang saling berkaitan secara hirarkis. Pada tingkat hirarki yang tertinggi ada makna-makna transendensi yang wajib diterima dan diyakini, sedangkan pada tingkat yang lebih rendah ada makna-makna yang bisa diinterpretasi atau diproduksi secara kreatif.

Yasraf Amir Piliang ${ }^{26}$ menjelaskan, Islam melihat dua hal ini sebagai sesuatu yang dapat dipadukan dan saling mengisi dengan harmonis. Pertama, mengikuti sebagai sesuatu yang wajib konvensi atau kode yang telah ditegaskan secara eksplisit dalam al-Qur'an dan Sunnah Nabi, menerimanya sebagai sesuatu yang transenden, dan sekaligus menjadikannya sebagai satu sistem kepercayaan atau ideologis, serta berupaya mengekspresikannya melalui sistem signifikasi bahasa. Pengertian ini tidak berbeda dengan istilah yang dikenal dalam studi uculsal-fiqh, yaitu qat;i sal-dilālah, suatu kata yang memiliki makna yang pasti, jelas, dan tidak memiliki kemungkinan-kemunkinan makna lain.

Kedua, menggali kemungkinan-kemungkinan pembaharuan penanda atau petanda melalui pintu ijtihad, untuk hal-hal yang belum ditegaskan secara eksplisit (dalam al-Qur'an dan Sunnah),

26Piliang, H ipersemiotika, 206. 
serta terbuka bagi interpretasi (terlebih masalah-masalah muamalah) dengan menggunakan model significance, sejauh tetap menguji kompatibilitasnya dengan kode-kode yang lebih tinggi. Istilah ini semakna dengan "anni zal-dilālah, yaitu sebuah kata yang memiliki kemungkinankemungkinan makna lain (interpretatif), atau kata yang memiliki ruang dan wilayah untuk melakukan ijtihad dalam rangka mencari pemahaman baru.

Misalnya, Islam menganjurkan kepada pemeluknya untuk berpakain dengan menutup awrat. Pakaian di dalam Islam sebagai satu tanda yang harus bersandar pada sistem tanda pada tingkat ideologis, berlandaskan konvensi dan kode tertinggi (untuk kesopanan dan kepatuhan), dan ini harus tercermin pada pertandaan. Akan tetapi, proses penafsiran pakaian sebagai satu sistem bahasa pada tingkat yang lebih rendah, misalnya dikaitkan dengan konteks musim, tren, mode, atau dikaitkan dengan budaya dan kultur setempat maka dapat dilakukan melalui proses dekonstruksi secara bebas dari makna yang konvensional, melalui permainan dekonstruksi dan significance bentuk, warna, motif, corak yang kreatif selama ia tidak bertentangan dengan kode ideologis. Di sini pertandaan bisa bersifat sewenang-wenang. J adi, interpretasi terhadap "pakaian" sebagai tanda akan menemukan referensi yang beraneka sesuai dengan perkembangan budaya.

Namun tidak semua tanda dapat diubah dengan sewenang-wenang, khususnya tandatanda yang berkaitan dengan rantai komunikasi antara manusia dan Tuhan. Komunikasi ini, khususnya dalam kerangka ibadah memiliki bentuk atau gerakan ritual tertentu, yang secara semiotik dapat dianggap sebagai seperangkattanda berdasarkan konvensi. Yang menjadi masalah adalah, bahwa tidak semua tanda dalam ibadah ini bersifat sewenang-wenang. Di antara tanda ini ada yang bersifat ikonik dan indeks. Merubah bentuk ibadah yang bersifat ikonik ini akan merubah konteks dan substansi makna secara keseluruhan.

Melontar jumrah misalnya, ia adalah satu bentuk pertandaan yang merupakan tiruan ikonik dari nabi Ibrahim yang melempari iblīs saat mengganggunya. Walaupun, dengan asumsi makna yang sama, yaitu mengusir iblīs, akan tetapi penanda ini tidak bisa dengan sewenang-wenang diganti secara kreatif, misalnya dengan panah, atau pistol, bukannya dengan kerikil. Sebab mengganti ikonik semacam ini akan memaksa dan merubah pemahaman manusia melebihi makna transenden-ideologis.

J uga dengan ikon-ikon yang lain, seperti shalat menghadap ke Baitullāh, mawāf dengan mengelilingi Ka'bah sebanyak tujuh kali, sa'i ilengan berlari-lari kecil antara bukit bafā dan Marwā ini semua adalah penanda dalam bentuk ikon yang memiliki petanda tertentu, sehingga tidak boleh diganti dengan bentuk penada-penanda lain sekalipun mempunyai asumsi makna yang sama. Begitu pula dengan penanda yang berbentuk indeks, seperti orang berwudlu' menunjukkan bahwa ia punya hadath kecil, seorang laki-laki berkhitan menunjukkan bahwa ia muslim (balīgh atau mukallaf), penanda ini tidak boleh secara sewenang-wenang diganti dengan bentuk penanda-penanda lain.

Dalam Islam wudlu' mempunyai cara-cara dan aturan-aturan tertentu, yang sepintas seakanakan tidak rasional. Sekalipun begitu penanda-penanda yang berkaitan dengan ibadah tidak dapat diganti secara sewenang-wenang dalam bentuk penanda-penanda lain. Karena ibadah dalam Islam yang menjadi keharusan bagi setiap pemeluknya mempunyai cara-cara tertentu, ada yang bersifat ta'abbudi łtidak bisa dirasionalisasikan) dan juga ada yang bersifat ta'aqquli> 
(bisa dirasionalisasikan). Namun, sebagian besar ibadah mahah adalah bersifat ta'abbudi,yaitu cara dan aturannya sudah ditentukan oleh Allah melalui Rasul-Nya Muhammad Saw.

\section{Penutup}

Dilihat dari sudut pandang semiotika, sebagian besar shariłah atau perintah-perintah Tuhan mengandung konvensi atau kode-kode, serta seperangkat tanda dan cara pengungkapan tertentu. Namun, konvensi tersebut dihasilkan berdasarkan penafsiran sesuai dengan budaya dan kultur setempat. Dalam Islam ada tiga sumber hukum, yaitu al-Q ur'an, Sunnah dan ijtihad. J ika dari sumber pertama tanda belum memperlihatkan kode dan makna yang eksplisit, maka makna dan kode tersebut harus dicari pada Sunnah Nabi. Dan jika tidak ditemukan pada keduanya, maka makna dan kode bisa dilakukan dengan berijtihad (sesuai dengan hæक्षith Mu'adh bin J abal), yaitu dengan melakukan pembongkaran dan dekonstruksi guna menemukan kode-kode tertentu sesuai dengan budaya yang ada demi kemaslahatan hidup manusia. Namun yang perlu diingat, bahwa ijtihad di sini sangat bergantung pada seperangkat tanda tak eksplisit dari alQur'an dan Sunnah Nabi, sehingga hasil penafsiran dan pemahaman tersebut tidak menerobos dan menundukkan kedudukan pesan dan makna yang bersifat transenden dan ideologis.

Karena itu, pemahaman baru terhadap al-Qur'an bukan berarti mereduksi, tetapi membuktikan sejauh mana al-Qur'an mampu berdialog dengan realitas. Teks, selayaknya dimaknai kembali secara komprehensif, inklusif dan substantif untuk menghindari pemahaman yang parsial, eksklusif dan formalistik. Dengan begitu, Islam yang diyakini sebagai agama S,̧lilih\} İ̄ kull zamān wa makān dan membawa misi rahmah li al-'alamīn bukan saja menjadi retorika, melainkan sebuah kenyataan.

\section{Daftar Rujukan}

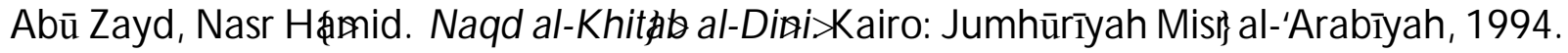

Bertens, K. Filsafat Barat Kontemporer Prancis. J akarta: G ramedia, 2001.

Budiman, Kris. Semiotika Visual . Yogyakarta: Buku Baik, 2004.

Eco, U mberto. A Theory of Semiotics. Bloomington: Indiana University Press, 1976.

Hidayat, Komaruddin. Memahami Bahasa Agama: Sebauh Kajian Hermeneutik. Jakarta: Paramadina, 1996.

Izutsu, Toshihiko. Relasi Tuhan dan Manusia: Pendekatan Semantik terhadap al-Qur'an, ter. Agus Fahri Husein, dkk. Yogyakarta: PT Tiara Wacana Yogya, 1997.

Krampen, Martin. "Ferdinand de Saussure dan Perkembangan Semiologi" dalam Serba-Serbi Semiotika, penyunting Panuti Sudjiman dan Aart van Zoest. J akarta: PT G ramedia Pustaka Utama, 1996.

Meuleman, J ohan. "Sumbangan dan Batas Semiotika dalam Ilmu Agama", dalam Tradisi, Kemodernan dan M etamodernisme: Memperbincangkan Pemikiran Muhammed Arkoun, ed. J ohan Hendrik Meuleman. Yogyakarta: LKiS, 1996.

Piliang, Yasraf Amir. Hipersemiotika: Tafsir Cultural Studies atas Matinya Makna. Yogyakarta: J alasutra, 2003. 
Rahardjo, Mudjia. Wacana Kebahasaan dari Filsafat Hingga Sosial-Politik. Malang: Cendekia Paramulya, 2004.

Sobur, Alex. Analisis Teks Media: Suatu Pengantar untuk Analisis Wacana, Analisis Semiotik, dan Analisis Framing. Bandung: Rosda Karya, 2001.

- - - - - . Semiotika Komunikasi. Bandung: Remaja Rosdakarya, 2004.

Wibowo, Wahyu. Manajemen Bahasa, Pengorganisasian Karangan Pragmatik dalam Bahasa Indonesia untuk Mahasiswa dan Praktisi Bisnis. J akarta: Gramedia Pustaka U tama, 2001. Zoest, Aart van. "Interpretasi dan Semiotika" dalam Serba-Serbi Semiotika. J akarta: Gramedia Pustaka Utama, 1996. 